\title{
Trends and variability of meteorological drought over the districts of India using standardized precipitation index
}

\author{
P Guhathakurta* (i), Preetha Menon, P M Inkane, Usha Krishnan and S T Sable \\ India Meteorological Department, Shivajinagar, Pune 411 005, India. \\ *Corresponding author.e-mail: pguhathakurta@rediffmail.com
}

MS received 27 February 2017; revised 26 April 2017; accepted 7 June 2017; published online 2 December 2017

Meteorological drought during the southwest monsoon season and for the northeast monsoon season over five meteorological subdivisions of India for the period 1901-2015 has been examined using district and all India standardized precipitation index (SPI). Whenever all India southwest monsoon rainfall was less than $-10 \%$ or below normal, for those years all India SPI was found as -1 or less. Composite analysis of SPI for the below normal years, viz., less than $-15 \%$ and $-20 \%$ of normal rainfall years indicate that during those years more than $30 \%$ of country's area was under drought condition, whenever all India southwest monsoon rainfall was $-15 \%$ or less than normal. Trend analysis of monthly SPI for the monsoon months identified the districts experiencing significant increase in drought occurrences. Significant positive correlation has been found with the meteorological drought over most of the districts of central, northern and peninsular India, while negative correlation was seen over the districts of eastern India with NINO 3.4 SST. For the first time, meteorological drought analysis over districts and its association with equatorial pacific SST and probability analysis has been done for the northeast monsoon over the affected regions of south peninsular India. Temporal correlation of all India southwest monsoon SPI and south peninsular India northeast monsoon SPI has been done with the global SST to identify the teleconnection of drought in India with global parameters.

Keywords. Meteorological drought; standardized precipitation index; monsoon; sea surface temperature.

\section{Introduction}

Drought is a normal recurring climatic phenomena that vary in space, time, and intensity. Drought is one of the most serious problems for human societies and ecosystems. It gradually establishes with the negative anomaly of rainfall for a required period and it is one of the most damaging types of natural disaster over long periods. It is necessary to know about the timing, locations, severity, and pattern of droughts for effective planning and decision making. This information helps officials and farmers to be more proactive in managing drought risks. Impacts of drought can be reduced through better understanding and identifying the appropriate drought indicators for an early warning system. It is being monitored by computing indices based on rainfall and many other parameters. In the last few decades, several drought indices have been developed based on several parameters, the details of which can be found in Heim (2002), Mishra and Singh (2010), and Dai (2011). Each index has its own merit and demerit and thus no single index has been able to adequately represent 
the intensity as well as severity of drought and its potential impacts on diverse group (Wilhite and Glantz 1985). The Palmer Drought Severity Index (PDSI, Palmer 1965) is one of the most widely used among various drought indices. PDSI is a climatic water balance index considering both precipitation and evapotranspiration anomalies as well as waterholding capacity of soil (Dai et al. 2004). The main shortcoming of PDSI lies in its lagged response of emerging droughts by several months, and its application is also limited in areas with frequent climatic extremes like in the Indian subcontinent (Niranjan et al. 2013).

The standardized precipitation index (SPI) is a probability-based indicator that depicts the degree to which the accumulative precipitation of a specific period departs from the average state. The SPI is space-independent and has a sound performance when representing precipitation anomaly, (McKee et al. 1993) compared with other indices and methods based on physical processes like the Palmer drought severity index (PDSI). SPI is easy to calculate and convenient to apply. It requires only precipitation as input data and escapes the problem of parameter calibration, thus is particularly suitable for drought/flood monitoring in areas where hydrological data is scarce (Yuan and Zhou 2004). As a result, SPI has already been widely used to characterize dry and wet conditions in many countries and regions, such as the United States (Wu et al. 2007), Canada (Quiring and Papakryiakou 2003), Italy (Piccarreta et al. 2004; Vergni and Todisco 2011), Iran (Moradi et al. 2011; Nafarzadegana et al. 2012), Korea (Min et al. 2003; Kim et al. 2009), and China. Bordi et al. (2004) applied SPI to analyse the spatiotemporal variability of dry and wet periods during the last 50 years in eastern China. They found that the northern part of eastern China had been experiencing dry conditions more frequently since the 1970s, and they concluded that the cycles ranged from 4 to 16 years. Zhai et al. (2010) also used SPI and PDSI to investigate the spatial variation and trends of dry and wet conditions in 10 large regions covering the territory of China from 1961 to 2005. They found that the frequencies of occurrence of both dry and wet years for the whole period were lower for the southern region than for the northwest. In particular, an increasing frequency of wet years was detected in the upper and lower reaches of the Yangtze River. Zhang et al. (2008) explored the changes of dry/wet episodes in the Pearl River Basin in South China and indicated that the Pearl River Basin becomes drier during the rainy season and wetter in winter. SPI has also been widely used for drought monitoring and management (e.g., McKee et al. 1993; Hayes et al. 1999). Although, the SPI was originally developed for drought detection and monitoring, it can also be applied to identify wetter than normal conditions. Seiler et al. (2002) analysed the potential of using SPI as a tool for monitoring flood risk in the Southern Cordoba Province in Argentina. They found that SPI satisfactorily explains the development of conditions leading up to the three main flood events in the region. However, very few studies have examined the capability of SPI to monitor hydrological floods, especially the relationship between SPI values at multiple time scales and monthly river discharges. Guhathakurta (2003) has analysed the district data during the all India normal monsoon years and found the probability of drought using percent of normal. Pai et al. (2011) have studied the southwest monsoon data for the period 1901-2003 for the 458 districts of India using SPI and compared the results with percent of normal. Patel et al. (2007) have analysed the spatial pattern of SPI and used correlation analysis to evaluate the usefulness of SPI to quantify effects of drought on food grain productivity over different areas of Gujarat in India, using station data. Using gridded data for the period 1951-2007, Niranjan et al. (2013) have done spatio-temporal analysis of SPI over India. Again, using gridded dataset for the period 1901-2004, Mallya et al. (2016) have analysed standard precipitation index (SPI), standardized precipitation-evapo transpiration index (SPEI), Gaussian mixture model-based drought index (GMM-DI), and hidden Markov model-based drought index (HMM-DI) and their trends over Indian region. Chanda and Maity (2015) have introduced a new index, viz., standardized precipitation anomaly index (SPAI) and have discussed advantages of it over SPI.

It has been observed that the variability of monsoon droughts over India is significantly influenced by the tropical sea surface temperature anomalies. Niranjan et al. (2013) using Canonical Correlation Analysis (CCA) have shown that the major portion of the drought variability is influenced by the El Nino/Southern Oscillation (ENSO). In addressing the causes and predictability of meteorological drought for any particular region of the world, the large-scale drivers (if any) of precipitation deficits relevant to that region are to be identified. Influence of ENSO, the abnormal warming 
phenomena in the equatorial pacific sea surface temperature (SST) in modulating the variability of Indian monsoon has been reported by several authors (Webster et al. 1998; Kucharski et al. 2006; Guhathakurta et al. 2015; etc.). However, for better understanding and application it is necessary for the state agricultural department to have detailed analysis of drought and its trends and variability in district scale. Most of the present analysis available is based on grid point data. The present study gives exhaustive analysis of meteorological drought over India using standardized precipitation index in district scale for the first time which will be particularly useful to the districts and state agricultural authorities for identifying those districts and adapting suitably to reduce the impacts of drought.

In the present analysis, we have used data for the period 1901-2015 and meteorological drought analysis has been done for 640 districts of India along with the probability of occurrence of drought in each category for each of the districts. Also, for the first time, a detailed drought analysis was done for the northeast monsoon of the southern peninsular Indian region affected by northeast monsoon (October-December). The results or findings of the analysis have multiple usefulness. Since rainfall has high spatial variability, seeing all India rainfall deficiency, one cannot make the conclusion about the severity of drought conditions in different parts of the country. However, present results shows that if all India southwest monsoon rainfall deficiency is less than $-15 \%, 30 \%$ or more area of the country is under drought condition. The probability of drought occurrence as well as the impact of climate changes on meteorological drought in different districts of the country will be very helpful for the drought management authorities as these information have been frequently demanded by them. The SPI analysis for the northeast monsoon has been done for the first time as this is the primary rainy season for the south peninsular India.

\section{Data and methodology}

\subsection{Data}

In India, district is being considered as smallest geographical administrative unit. Thus, real time information on rainfall situation over the districts are necessary prerequisite for the state government authorities for water, agricultural and disaster managements. To meet the demands, India Meteorological Department has started real time district rainfall monitoring since 1992 . However, due to lack of long series of rainfall data, it was not possible to provide drought monitoring in the district scale before 2013. In the present study, we have used 115 years (1901-2015) of long series of monthly rainfall data of 640 districts of India (Guhathakurta et al. 2011). The use of 115 years of long series data makes stronger confidence in probability estimates based on SPI. According to WMO (2012), use of lesser sample size, particularly minimum 30 years of data (or less) shortens the sample size and weakens the confidence. Even McKee et al. (1993) have recommended the use of continuous period of at least 30 years in their pioneer paper while introducing SPI for the first time. Monthly rainfall data of nearly 6000 rain gauge stations are being used for the construction of district rainfall series.

\subsection{Methodology}

\subsubsection{Standardized precipitation index: Methodology}

The standardized precipitation index (SPI) has been computed by fitting a Gamma probability density function to the frequency distribution of precipitation summed over the time scale of interest ( 1 month for individual monsoon months, 3 and 4 for northeast monsoon and southwest monsoon, respectively). This is performed separately for each time scale and for each district. Details of computation of SPI have been taken from Hughes and Saunders (2002). Each probability density function is then transformed into the standardized normal distribution.

Thus, the SPI is said to be normalized in location and time scale. Once standardized, the different categories are used here for classifying the severity of drought along with their theoretical probabilities of occurrence arising from the normal probability density function as given in table 1 .

Calculation: The monthly precipitation time series are modelled using the gamma distribution, whose probability density function is defined as

$$
g(x)=\frac{1}{\beta^{\alpha} \Gamma(\alpha)} x^{\alpha-1} e^{-x / \beta} \quad \text { for } x>0,
$$

where $\alpha>0$ is a shape parameter, $\beta>0$ is a scale parameter, and $x>0$ is the amount of precipitation. 
Table 1. SPI values and different categories of wetness/dryness along with their theoretical probabilities of occurrence arising from the normal probability density function.

\begin{tabular}{llc}
\hline SPI value & Category & $\begin{array}{c}\text { Theoretical } \\
\text { probability }\end{array}$ \\
\hline 2.00 or more & Extremely wet & 2.3 \\
1.50 to 1.99 & Severely wet & 4.4 \\
1.00 to 1.49 & Moderately wet & 9.2 \\
0 to 0.99 & Mildly wet & 34.1 \\
-0.99 to 0 & Mildly dry & 34.1 \\
-1.49 to -1.00 & Moderately dry & 9.2 \\
-1.99 to -1.50 & Severely dry & 4.4 \\
-2.0 or less & Extremely dry & 2.3 \\
\hline
\end{tabular}

Fitting the distribution to the data requires $\alpha$ and $\beta$ to be estimated. Edwards and McKee (1997) suggested estimating these parameters using the approximation of Thom (1958) for maximum likelihood as shown below:

$$
\begin{gathered}
\hat{\alpha}=\frac{1}{4 A}\left(1+\sqrt{1+\frac{4 A}{3}}\right) \\
\hat{\beta}=\frac{\bar{x}}{\hat{\alpha}}
\end{gathered}
$$

where for $n$ observations,

$$
A=\ln (\bar{x})-\frac{\sum \ln (x)}{n} .
$$

The period 1901-2000 is taken as base period for fitting the probability distribution. Integrating the probability density function with respect to $x$ and inserting the estimates of $\alpha$ and $\beta$ yields an expression for the cumulative probability $G(x)$ of an observed amount of precipitation occurring for a given month and time scale is obtained. Since the gamma distribution is undefined for $x=0$, we have then used incomplete gamma distribution, viz., $H(x)=q+(1-q) G(x)$, $q=P(x=0)>0$, where $P(x=0)$ is the probability of zero precipitation. The cumulative probability distribution is then transformed into the standard normal distribution to yield the SPI. In order to examine the spatial pattern of dry/wet conditions during the years when all India southwest monsoon rainfall was deficient, the composite that is the average SPI values of the district of selected years has been computed. In order to see the probability of drought occurrences in each of the district in different categories (moderate, severe or extremely severe) of events as well as for all combine categories over the country, we have prepared all India frequency time series of each of the category for all the districts. Probability has been calculated for each district and for each category based on the frequency of occurrences of the event in the sample data.

\subsubsection{Mann-Kendall trend test}

Most widely used method for detecting the trend is the non-parametric Mann-Kendall trend test. Mann (1945) originally derived the test and Kendall (1975) subsequently derived the test statistic commonly known as the Kendall's tau statistic. It was found to be an excellent tool for trend detection in different applications (Hirsch et al. 1982; Lettenmaier et al. 1994; Burn and Hag-Elnur 2002).

To find the amount of increase or decrease, we have adopted least square linear fit of the data. Advantage of linear regression is that it provides an estimate of slope, confidence interval, and quantifies goodness-of-fit.

\section{SPI analysis for southwest monsoon season}

Southwest monsoon over India has shown natural climate variability with multi-decadal epochs of dry and wet period. Figure 1 shows the all India SW monsoon rainfall in percentage departure of long period averages along with 9 point and 11 point filters. India Meteorological Department which is the national agency for meteorological and weather services of India uses the terminology of below normal rainfall in a particular southwest monsoon season if percentage departure from long period average is less than 10\%. During 115 years period, there were 24 years when rainfall departure was less than $-10 \%$ and thus were below normal years. Figure 1 also shows the four months (JuneSeptember) cumulative standardized precipitation index values during the period. It can be seen that in all the years when southwest monsoon rainfall was below normal, SPI values were -1 or less and thus in moderate, severe or extremely severe drought categories. During the period 1901-2015, there were four years, viz., 1965, 1972, 2002 and 2009, when SPI was in the extremely dry category and out of that 1972 was the most. However, 


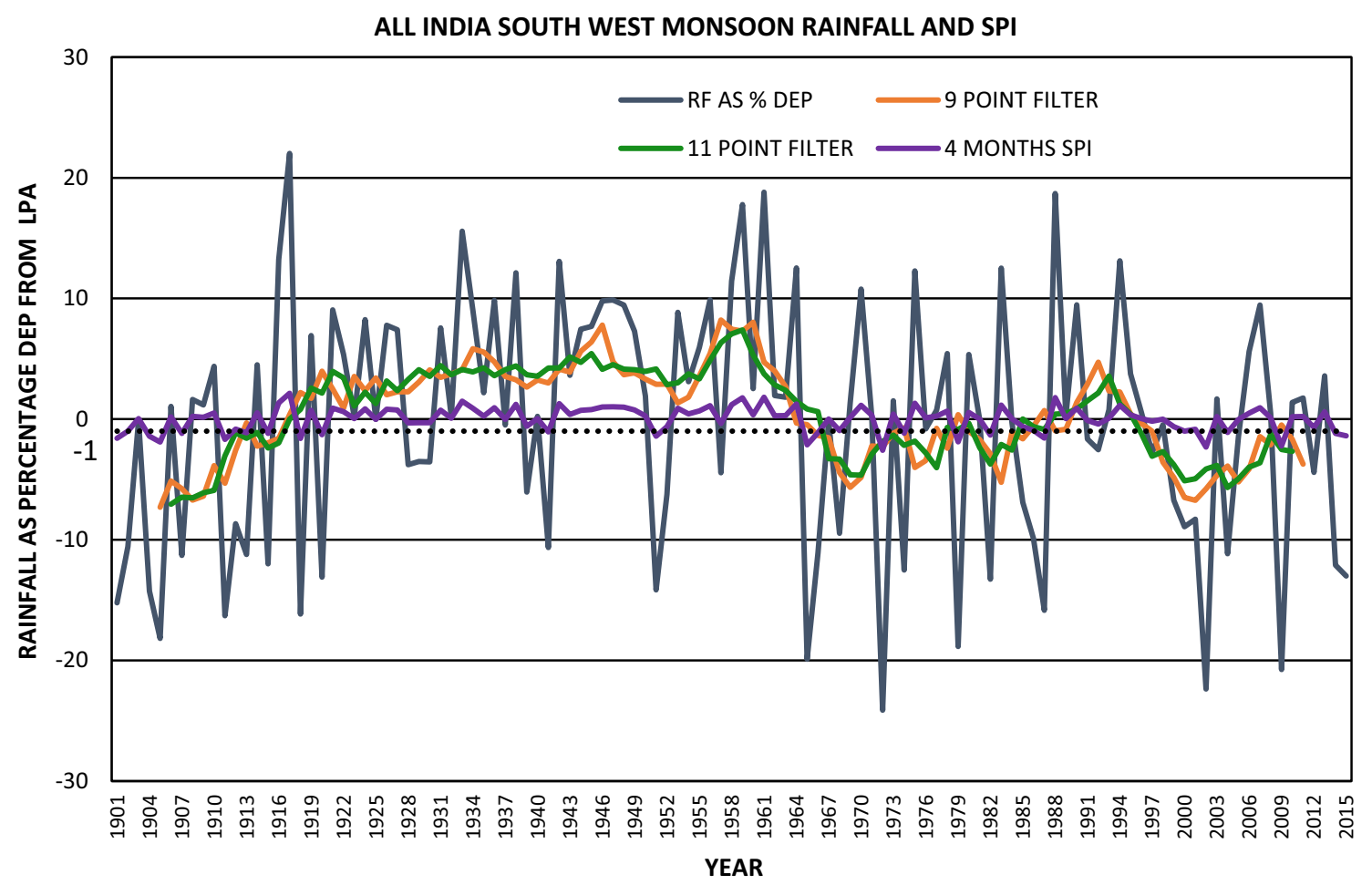

Figure 1. All India southwest monsoon rainfall along with its 9 and 11 years running mean and standardized precipitation index.

due to the presence of high spatial variability, it is required to investigate pattern of SPI in smaller geographical scales (district). Figure 2 gives the composite SPI district maps for the southwest monsoon season in three categories for the years (a) when the all India southwest monsoon rainfall was below normal, (b) having $-15 \%$ or less than normal monsoon rainfall and (c) having $-20 \%$ or less than normal monsoon rainfall, while table 2 gives the percentage of areas of the country in different dry and wet categories of SPI during these three cases. Figure 2(a and b) shows that there was no district under moderate or higher wet categories. In the first two cases, i.e., when the all India southwest monsoon rainfall was less than $-10 \%$ and when it was less than or equal to $-15 \%$ of normal, no district has reported moderate or higher categories of wet conditions. When all India rainfall was less than or equal to $-20 \%$, only one district of Arunachal Pradesh has reported severely wet condition. Most of the districts reporting mildly wet category are from the eastern and north-eastern states. For the composite years of SPI, when all India rainfall was less than $-10 \%$, only $7.5 \%$ of the area of the country was under moderate drought category while $88 \%$ was under mildly dry category. However, more than $30 \%$ of the area of the country was under moderate/severe/extreme drought conditions when all India rainfall was less than or equal to $-15 \%$ or $-20 \%$ of normal. This suggests that by seeing the all India southwest monsoon rainfall itself, the monsoon year can be considered as all India drought year if the rainfall is less than or equal to $-15 \%$ of its normal.

\subsection{Trends in district SPI}

Figure 3 shows the trends in SPI during the months June, July, August and September and for the four-month cumulative period June-September. Decrease in SPI values are seen over many districts of central India and extreme south peninsular India during the months of June, July and September, while in August it was over eastern, north-eastern and Tamil Nadu region. SPI values have shown significant decreasing trends indicating increasing drought scenario over many districts of east MP, Bihar, Jharkhand, east UP, Punjab, Uttarakhand, Kerala and northeast states during July and August. While more number of districts show significant decreasing trend in August than July, but for the state of Kerala, the decreasing trends are not significant. In four 
(a)

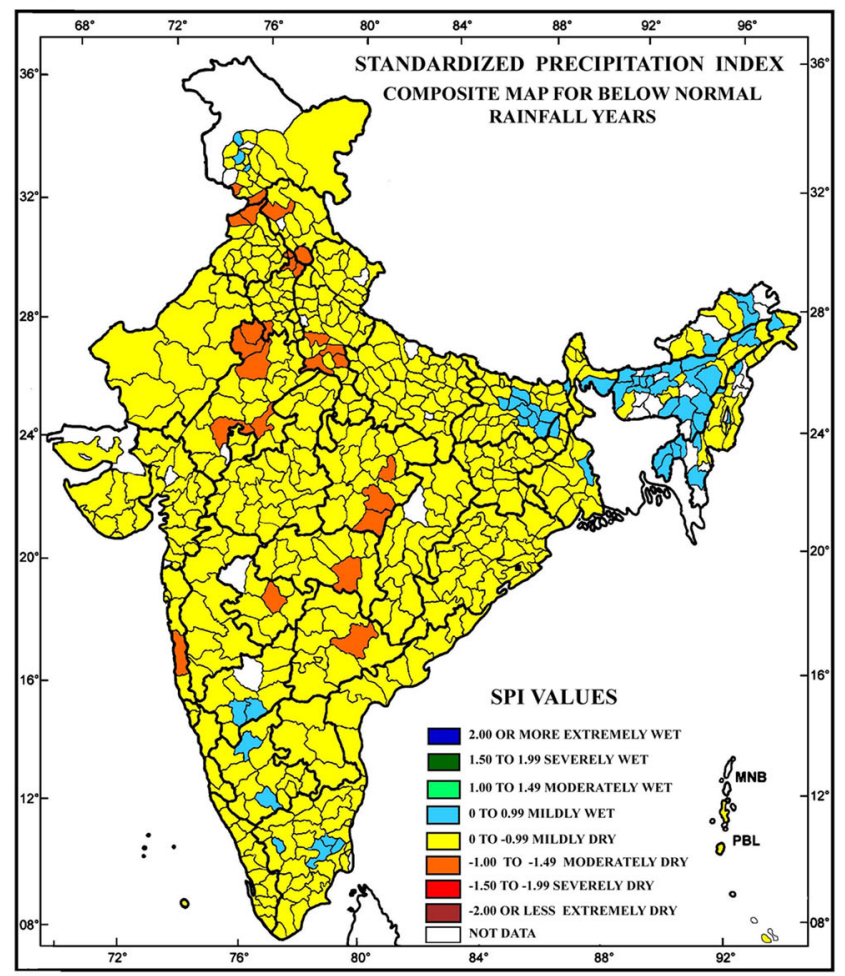

(b)

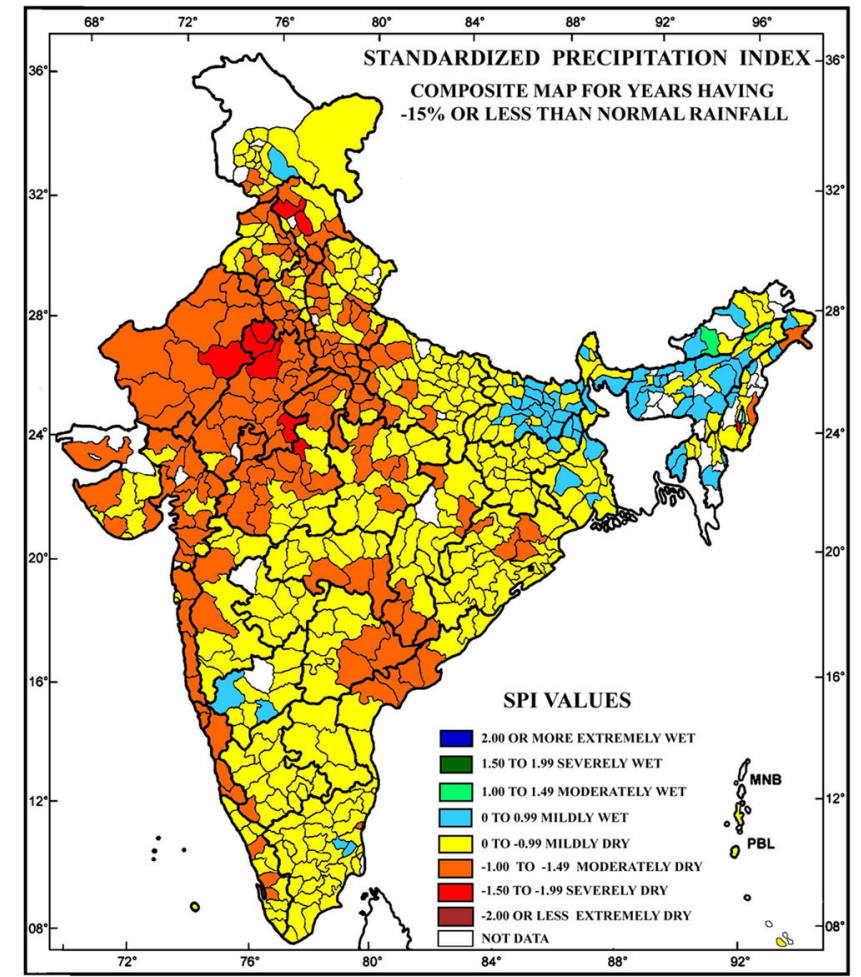

(c)

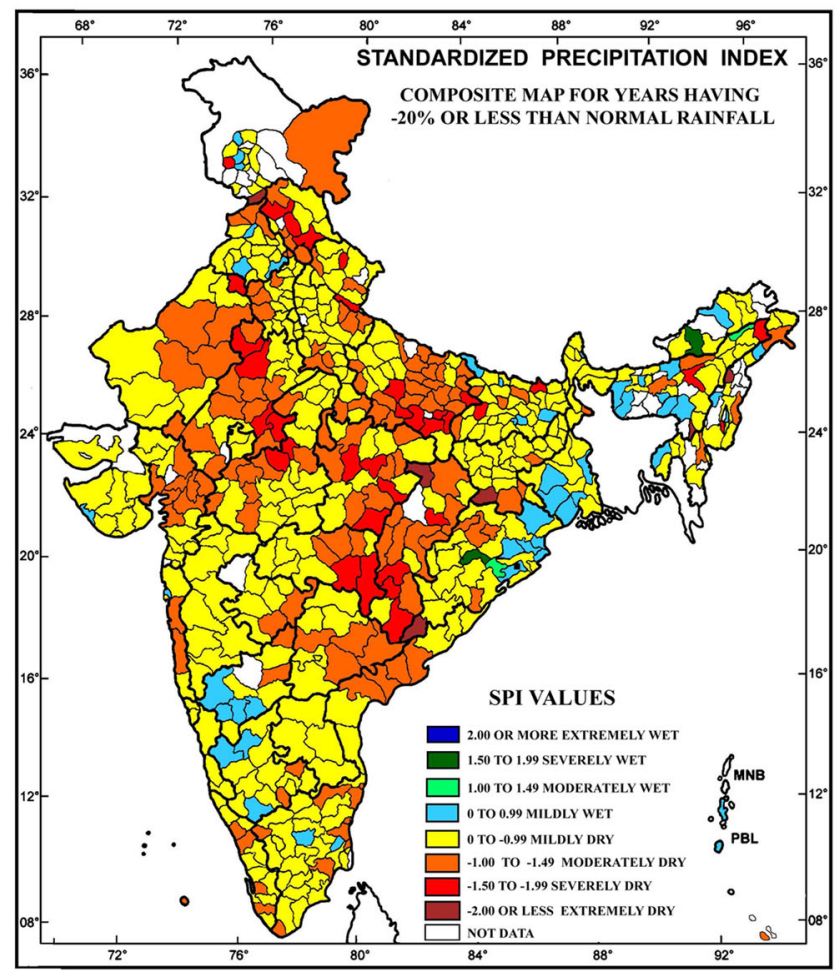

Figure 2. Composite district standardized precipitation index maps for southwest monsoon season for all India (a) below normal monsoon years, (b) years having $-15 \%$ or less than normal monsoon rainfall, and (c) years having $-20 \%$ or less than normal monsoon rainfall.

months, June-September SPI, significant decreasing trends are being noticed over Bihar, east UP, Chhattisgarh, Jharkhand, east MP and adjoining areas, Himachal Pradesh, Uttaranchal and adjoining areas in the north Assam and adjoining areas in northeast as well as Kerala and adjoining 
Table 2. Percentage of areas of the country under different SPI categories when the all India southwest monsoon rainfall was less than $-10 \%$ of normal.

\begin{tabular}{|c|c|c|c|c|c|c|c|c|}
\hline \multirow[b]{2}{*}{$\begin{array}{l}\text { All India SW } \\
\text { monsoon rainfall }\end{array}$} & \multicolumn{8}{|c|}{ Percentage of area of the country } \\
\hline & $\begin{array}{c}\text { Extremely } \\
\text { wet }\end{array}$ & $\begin{array}{c}\text { Severely } \\
\text { wet }\end{array}$ & $\begin{array}{c}\text { Moderately } \\
\text { wet }\end{array}$ & $\begin{array}{l}\text { Mildly } \\
\text { wet }\end{array}$ & $\begin{array}{l}\text { Mildly } \\
\text { dry }\end{array}$ & $\begin{array}{c}\text { Moderately } \\
\text { dry }\end{array}$ & $\begin{array}{c}\text { Severely } \\
\text { dry }\end{array}$ & $\begin{array}{c}\text { Extremely } \\
\text { dry }\end{array}$ \\
\hline$<-10 \%$ of normal & 0 & 0 & 0 & 7.5 & 87.8 & 4.5 & 0 & 0 \\
\hline$\leq-15 \%$ of normal & 0 & 0 & 0.2 & 8.2 & 54.2 & 33.8 & 2.0 & 0 \\
\hline$\leq-20 \%$ of normal & 0 & 0.1 & 0.2 & 6.7 & 58.7 & 25.1 & 5.8 & 0.7 \\
\hline
\end{tabular}

areas in south. The trend pattern in SPI for the southwest monsoon season is similar to that of Pai et al. (2011). But number of districts showing significant positive or negative trends are more here than Pai et al. (2011) as the number of districts in their analysis was much less and also data period was less (1901-2003). Using the gridded data for period 1901-2004, Mallya et al. (2016) have also obtained almost similar patterns in decreasing trends in 12-month SPI ending September. But in their analysis with gridded data, they have not shown any significant results of trends. Table 3(a) shows the subdivision-wise districts showing significant decreasing trends in the cumulative SW monsoon period SPI. Most affected subdivisions are east Uttar Pradesh, Bihar and Assam, and Meghalaya, where 16, 15 and 13 number of districts respectively showed decreasing trends in SPI, indicating increase in drought occurrences. The regions in western and southwestern parts of the country, viz., east and west Rajasthan, west Madhya Pradesh, Saurashtra \& Kutch, Konkan \& Goa, Madhya Maharashtra, coastal and south interior Karnataka and also in eastern sides, viz., coastal Andhra Pradesh, and Gangetic West Bengal have no districts showing decrease in SPI or increase in drought occurrences. Table 3(b) shows the districts where SPI is increasing indicating decrease in drought occurrences. For the southwest monsoon season, SPI has significantly decreased over 132 districts of the country, mostly over central and north eastern India while 56 districts have shown significant increase in SPI.

\subsection{Probability of drought occurrences}

In order to see the probability of drought occurrences in each of the district in moderate, severe or extremely severe events as well as for all combined categories over the country, we have prepared all India frequency time series of each of the category for all the districts. Figure 4 shows the probability of drought occurrences in each of the moderate, severe, extremely severe and combination of moderate, severe, extremely severe categories which has been calculated based on the data for the period 1901-2015 for the southwest monsoon period (June-September) over India. Probability of moderate drought pattern is almost similar to that of Pai et al. (2011) obtained with less number of districts and data period, but the present results for the severe and extremely severe categories are more consistent with the theoretical probability than the results shown by Pai et al. (2011). They have reported that the probabilities of severe and extremely severe drought have exceeded $15 \%$ in some districts against their theoretical probabilities of $4 \%$ and $2 \%$, respectively. There are many districts where the probability of drought occurrence for each of the category is little more than the theoretical probability given in table 1 . From figure 4(d) which gives the probability of drought occurrence combining all categories, it can been seen that the districts having probability more than the theoretical probability are located in all parts of the country, except for the northeastern states.

\subsection{Trends in percentage area under drought condition}

We have prepared time series of percentage of areas under drought condition (SPI in the moderately dry, severely dry or extremely severe dry conditions) for each of the 36 meteorological subdivisions by considering number of districts in each year and its total areas by summing the district areas for the respective subdivision and dividing the total areas of the that subdivision for the period 1901-2015. Trend analysis was then done on the time series of percentage of areas under drought condition to see the changes in the area 
(a)

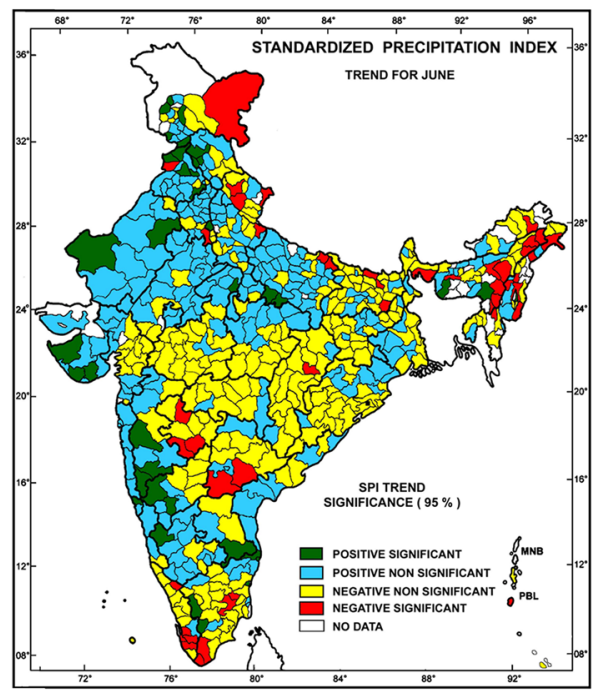

(c)

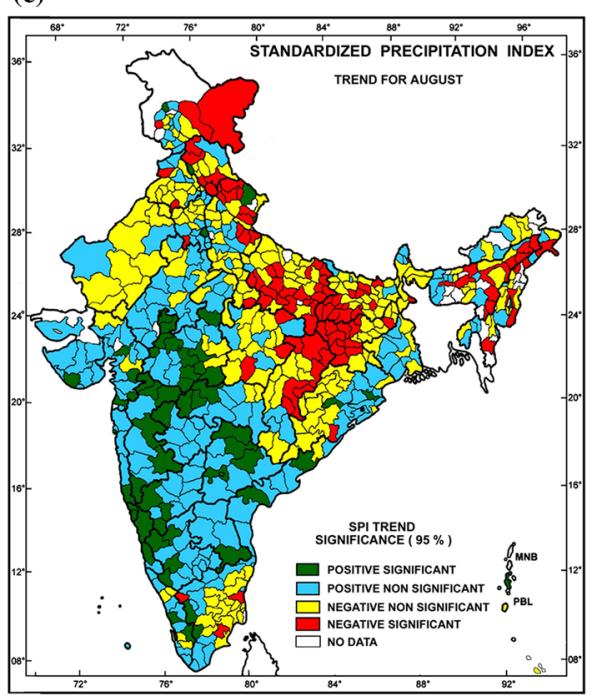

(b)

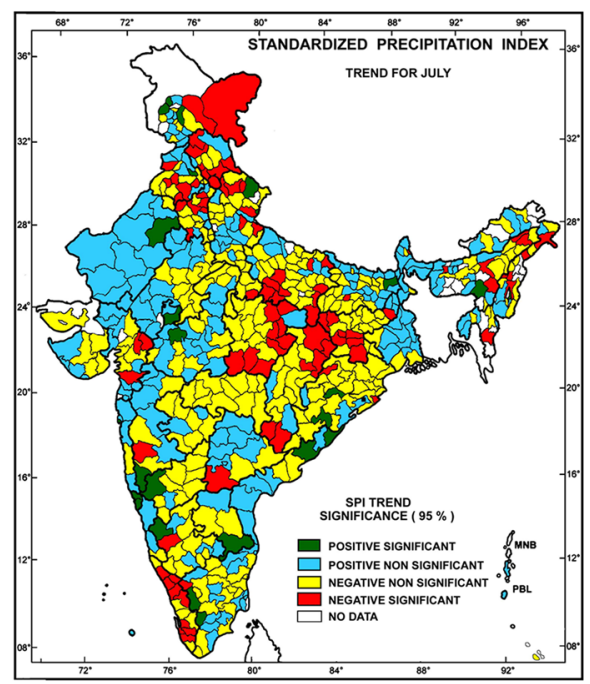

(d)

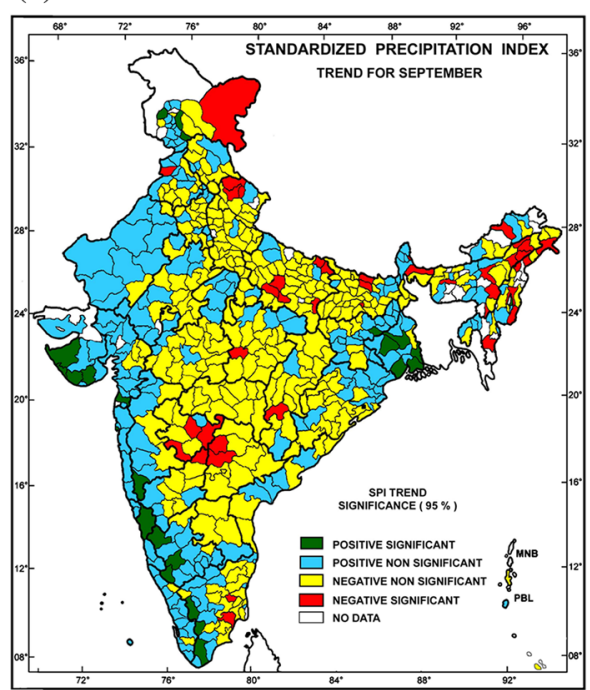

(e)

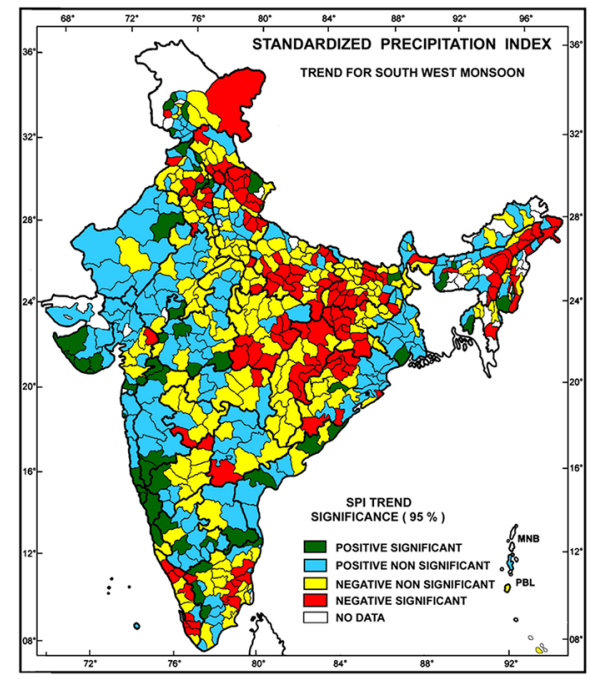

Figure 3. Trends in district SPI for the four monsoon months and for the southwest monsoon season. 
Table 3. Meteorological subdivisions, number of districts and the districts having decreasing and increasing trend in SPI.

Name of sub-division

Andaman \& Nicobar Island

Arunachal Pradesh

Assam \& Meghalaya

No. of districts

Name of districts

(1)

Anjaw, Changlang
Nagaland, Manipur, Mizoram, Tripura

Sub-Himalayan West Bengal and Sikkim

Gangetic West Bengal

Orissa

Jharkhand

Bihar

East Uttar Pradesh

West Uttar Pradesh

Uttaranchal

Haryana, Delhi and Chandigarh

Punjab

Himachal Pradesh

Jammu \& Kashmir

West Rajasthan

East Rajasthan

West Madhya Pradesh

East Madhya Pradesh

Gujarat Region

Saurashtra \& Kutch

Konkan \& Goa

Madhya Maharashtra

Marathwada

Vidarbha

Chhattisgarh

Coastal Andhra Pradesh

Telangana

Rayalseema

Tamil Nadu

Coastal Karnataka

North Interior Karnataka

South Interior Karnataka

Kerala

Lakshadweep
5

4

4

2

0

0

0

0

1

0

6

0

1

0

8
Cachar, Darrang, Goalpara, N.C. Hills, Nagaon, Sibsagar, Dibrugarh, Jorhat, Karbi Anglong,

Karimganj, Golaghat, Tinsukia, Hailakandi

Chandel, Senapati, Lunglei, Kohima, Mon

Jalpaiguri, East Sikkim

Deogarh, Gajapati, Jagatsinghpur, Jharsuguda,

Koraput, Sambalpur, Sundargarh

Chatra, Dumka, Garhwa, Gumla, Koderma,

Lohardaga, Palamu, West Singbhum, Latehar, Khunti

Aurangabad, Banka, Bhojpur, Buxar, Darbhanga,

Gaya, Jahanabad, Madhepura, Madhubani,

Nawada, Rohtas, Saharsa, Samastipur, Sheikhpura, Arwal

Allahabad, Ballia, Banda, Chandauli, Fatehpur,

Ghazipur, Kanpur City, Kaushambi, Kushi Nagar,

Lucknow, Maharajganj, Pratapgarh, Rae Bareilly,

Sant Kabir Nagar, Sultanpur, Sonbhadra

Auraiya, Bareilly, Pilibhit, Rampur, Mahoba

Almora, Dehradun, Nainital, Garhwal Pauri,

Garhwal Tehri, Uttarkashi, Rudraprayag

Karnal, Mahendragarh, Kurukshetra, Panipat, West Delhi

Mansa, Fatehgarh Sahib, Tarn Taran, Barnala

Chamba, Shimla, Sirmaur, Solan

Ladakh (Leh), Chamarajanagar

Balaghat, Chindwara, Dindori, Narsinghpur, Seoni, Shahdol, Sidhi, Umaria, Anuppur

Dahod

Osmanabad

Bhandara

Dhamtari, Janjgir, Koriya, Mahasamund, Raigarh, Raipur, Surguja

Mahbubnagar

Cuddalore, Nilgiri, Perambalur, Pudukkottai, Trichy, Viluppuram

Bidar

Alapuzha, Cannur, Kottayam, Kozhikode, Palakkad, Kollam, Pathanamthitta, Wynad 
Table 3. (Continued.)

\begin{tabular}{|c|c|c|}
\hline Name of Sub-division & No. of districts & Name of districts \\
\hline \multicolumn{3}{|c|}{ Districts with significant increasing trend in SPI } \\
\hline Andaman \& Nicobar Island & 0 & \\
\hline Arunachal Pradesh & 0 & \\
\hline Assam \& Meghalaya & 2 & Barpeta, West Garo Hills \\
\hline Nagaland, Manipur, Mizoram, Tripura & 3 & Churachandpur, Imphal East, South Tripura \\
\hline Sub-Himalayan West Bengal \& Sikkim & 0 & \\
\hline Gangetic West Bengal & 2 & East Midnapore, South 24 Pargana \\
\hline Orissa & 1 & Boudhgarh \\
\hline Jharkhand & 0 & \\
\hline Bihar & 1 & Purnea \\
\hline East Uttar Pradesh & 0 & \\
\hline West Uttar Pradesh & 0 & \\
\hline Uttaranchal & 2 & Chamoli, Champawat \\
\hline Haryana, Delhi \& Chandigarh & 1 & Ambala \\
\hline Punjab & 4 & Gurdaspur, Patiala, Ropar, Nawanshahar \\
\hline Himachal Pradesh & 1 & Una \\
\hline Jammu \& Kashmir & 4 & Anantnag, Baramula, Jammu, Kupwara \\
\hline West Rajasthan & 1 & Churu \\
\hline East Rajasthan & 0 & \\
\hline West Madhya Pradesh & 5 & Betul, Jhabua, Mandsaur, Ujjain, Burhanpur \\
\hline East Madhya Pradesh & 0 & \\
\hline Gujarat Region & 2 & Valsad, Dangs \\
\hline Saurashtra \& Kutch & 5 & Amreli, Jamnagar, Junagarh, Porbandar, Diu \\
\hline Konkan \& Goa & 4 & Mumbai City, Sindhudurg, North Goa, South Goa \\
\hline Madhya Maharashtra & 4 & Dhule, Kolhapur, Sangli, Nandurbar \\
\hline Marathwada & 0 & \\
\hline Vidarbha & 0 & \\
\hline Chhattisgarh & 0 & \\
\hline Coastal Andhra Pradesh & 3 & Guntur, Srikakulam, Vishakhapatnam \\
\hline Telangana & 0 & \\
\hline Rayalseema & 1 & Chittoor \\
\hline Tamil Nadu & 3 & Coimbatore, Theni, Tiruvallur \\
\hline Coastal Karnataka & 2 & Uttar Kannada, Udupi \\
\hline North Interior Karnataka & 1 & Belgam \\
\hline South Interior Karnataka & 4 & Bangalore Rural, Chamarajanagar, Hassan, Shimoga \\
\hline Kerala & 0 & \\
\hline Lakshadweep & 0 & \\
\hline
\end{tabular}

in each of the subdivision (figure 5). Seven subdivisions, viz., Uttarakhand, east Uttar Pradesh, Jharkhand, Chhattisgarh, Assam and Meghalaya, Nagaland-Manipur-Mizoram \& Tripura and Kerala have significant increasing trend in the areas under drought condition. Most of the parts of eastern and northeast India have increasing trend in percentage of areas under drought condition (SPI in the moderately dry, severely dry or extremely severe dry conditions). However, no subdivision shows significant decrease in area under drought condition though mostly western parts of the country show decreasing trend in percentage of area under drought condition.

\section{Northeast monsoon}

In India, most of the areas receive around 75$85 \%$ of its annual rainfall during the period JuneSeptember due to the influence of southwest monsoon. However, there are areas where most of its annual rain occurs during October-December due to the influence of northeast monsoon. Mostly, the five meteorological subdivisions, viz., Tamil Nadu \& Puducherry, coastal Andhra Pradesh, Rayalseema, south interior Karnataka and Kerala of India are nearly getting $30-45 \%$ of annual rainfall during the northeast monsoon season (OctoberDecember). Failure of the northeast monsoon in 
(a)

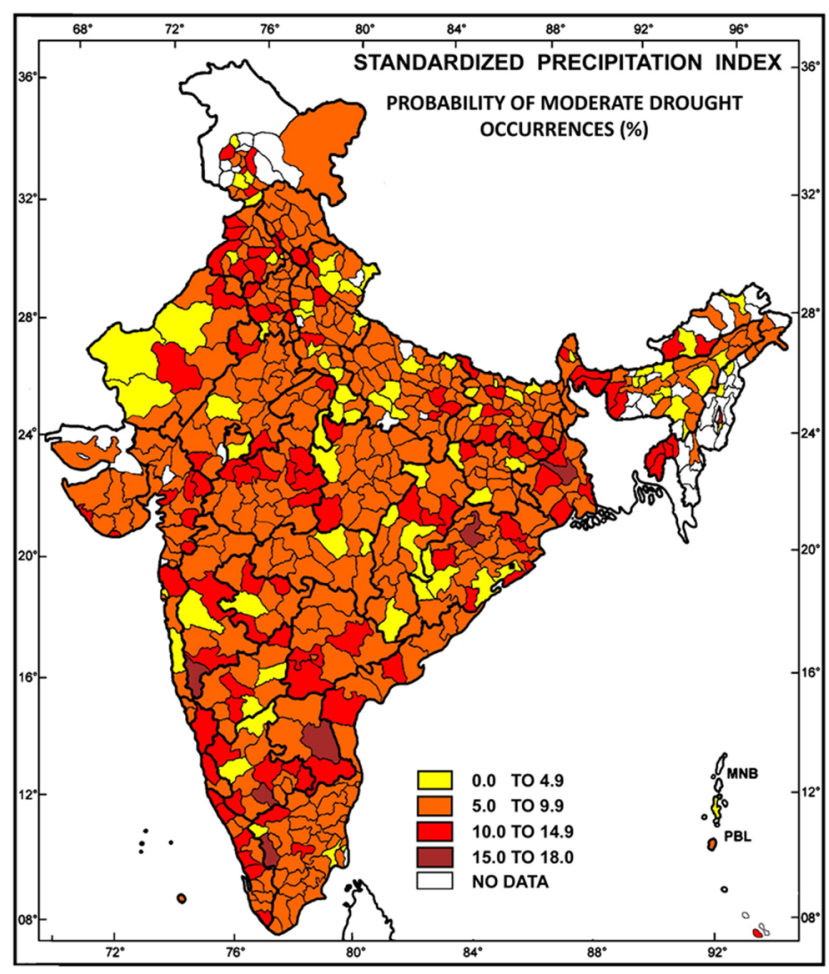

(c)

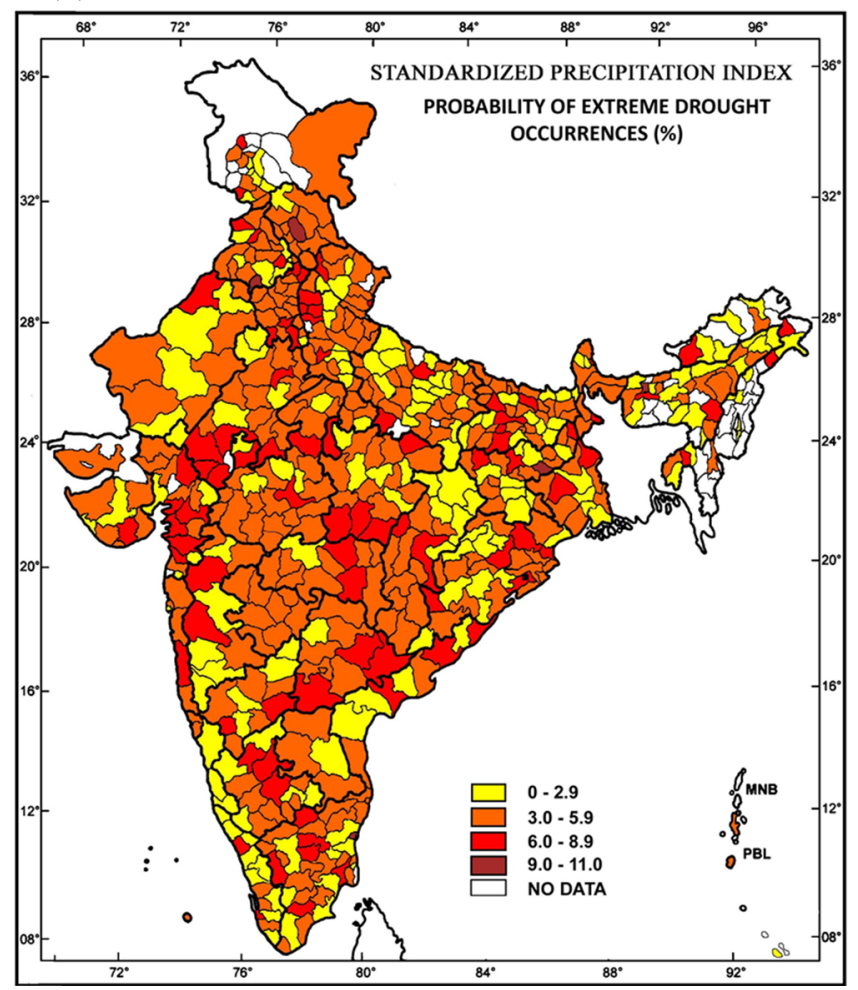

(b)

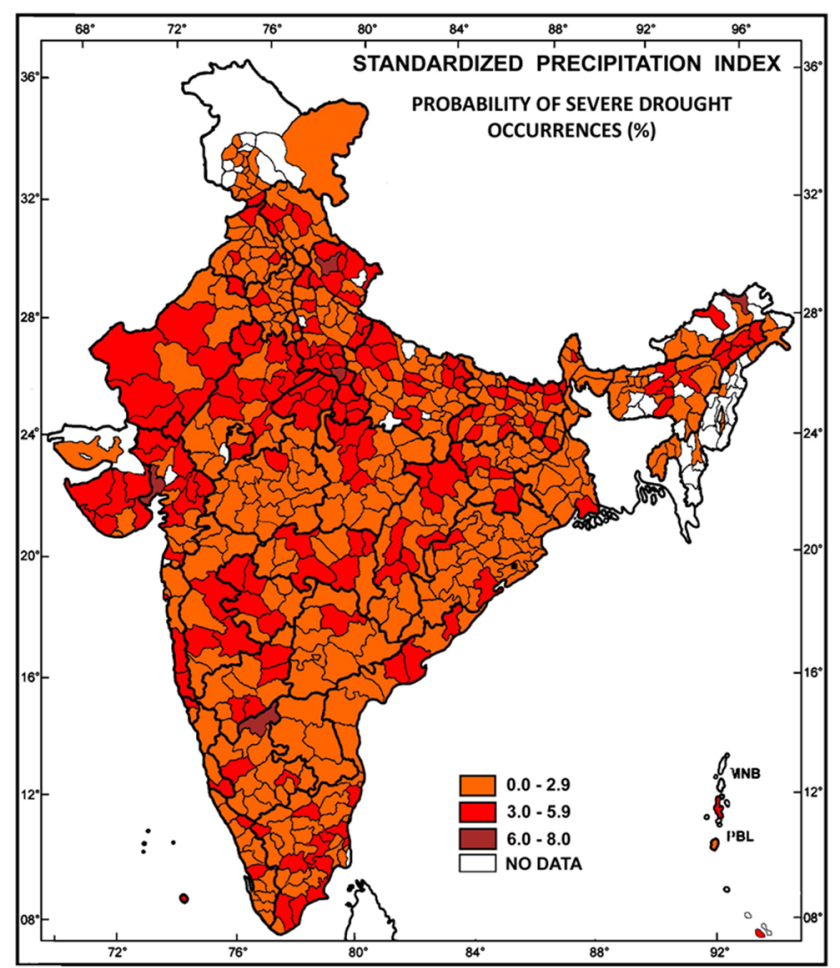

(d)

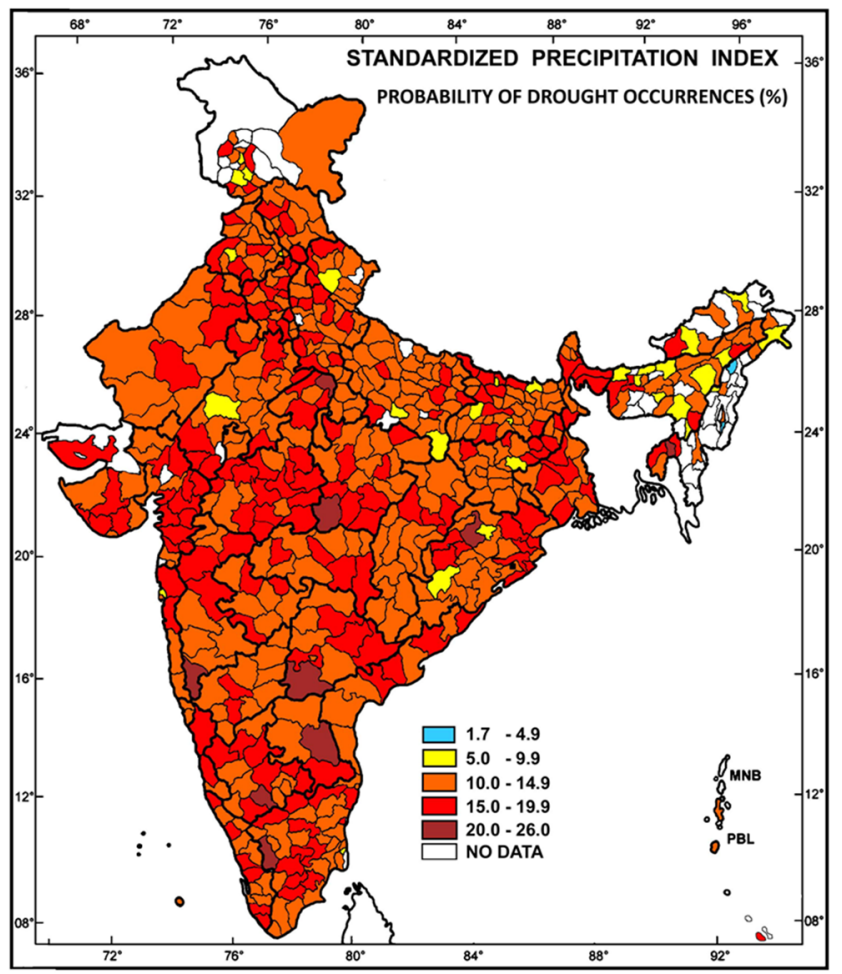

Figure 4. Probability of occurrences of (a) moderate drought, (b) severe drought, (c) extreme drought, and (d) all types of drought.

any year causes severe impact on the economy of these subdivisions. Therefore, our drought analysis is also extended to the districts of these five meteorological subdivisions as water requirement during this period is very crucial for agricultural planning over these areas. 


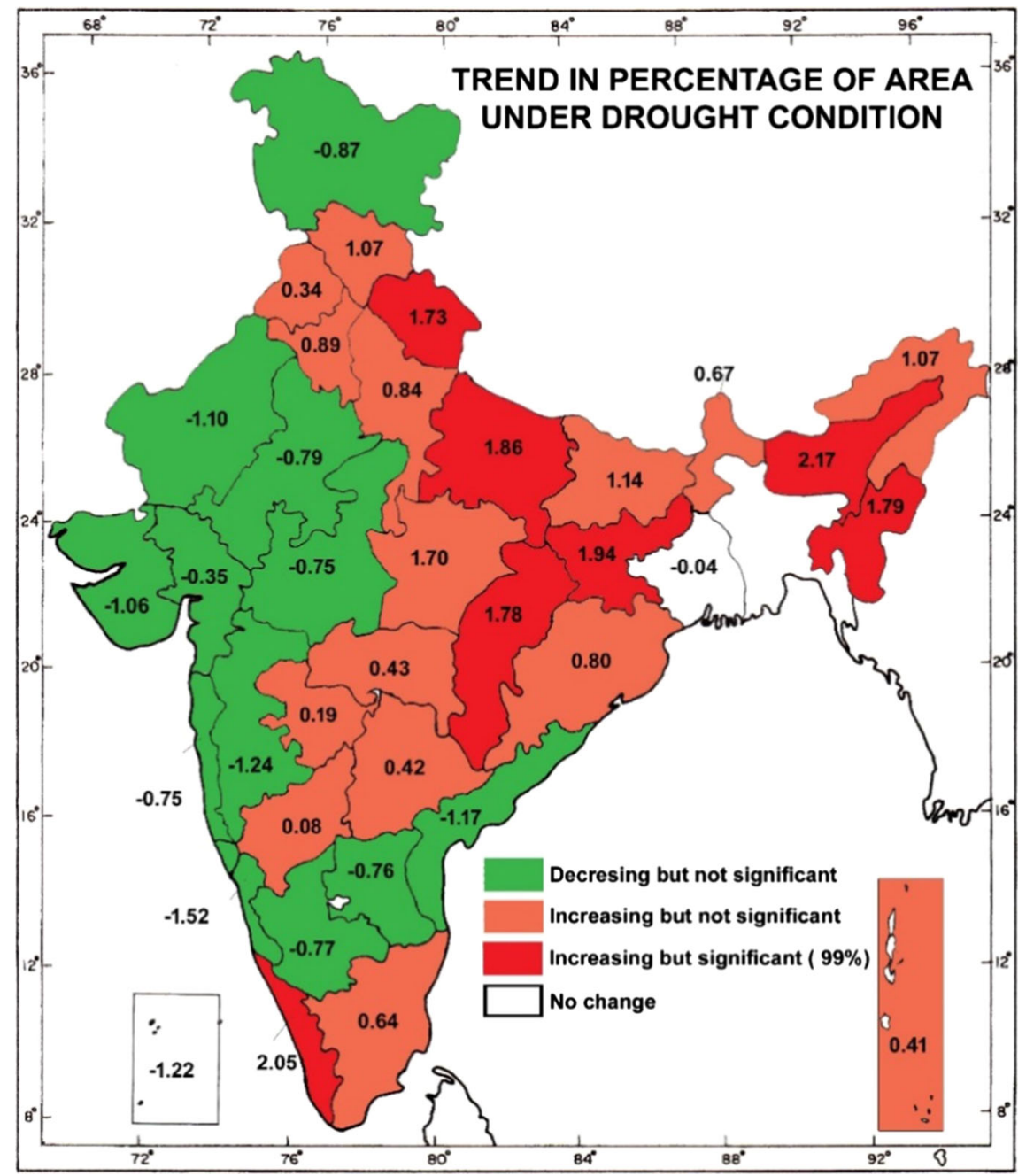

Figure 5. Trends in percentage of area under drought conditions.

\subsection{Trends in district SPI}

Figure 6 shows the trends in SPI for the month of October, November, and December and for the cumulative period October-December of these five meteorological subdivisions. Only two districts of Tamil Nadu in the central parts show significant decreasing trend in October SPI, while no other districts show any significant trend. No districts have shown any significant changes in November SPI but in December SPI, five districts of south interior Karnataka, four districts of Kerala and two districts of coastal Andhra Pradesh have shown significant decrease. For the northeast monsoon season October-December, one district of south interior Karnataka and one district of Kerala show significant decreasing trend, while one district of Tamil Nadu shows significant increasing trend in SPI. The meteorological subdivision, Tamil Nadu \& Puducherry is fully dependent on northeast monsoon season and this subdivision receives less than $45 \%$ of its annual rainfall during southwest monsoon season.

\subsection{Probability of drought occurrences}

Figure 7 shows the probability of drought occurrences in each of the moderate, severe, extremely severe and combination of moderate, severe, extremely severe categories which has been calculated based on the data for the period 1901-2015 for the northeast monsoon period (October-December) over India for the five affected meteorological subdivisions. Probability of moderate drought is around $6-10 \%$, while extreme drought is around $3-6 \%$ over most of the districts. Probability of drought of all types is maximum (20-26\%) in one district of coastal Andhra Pradesh and one district of Kerala while it is varying from 
(a)

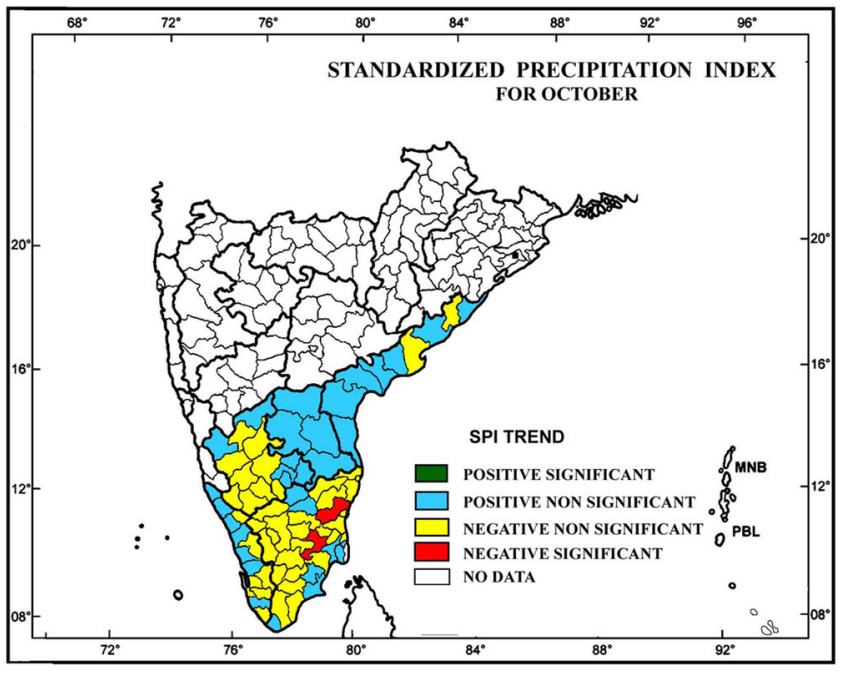

(c)

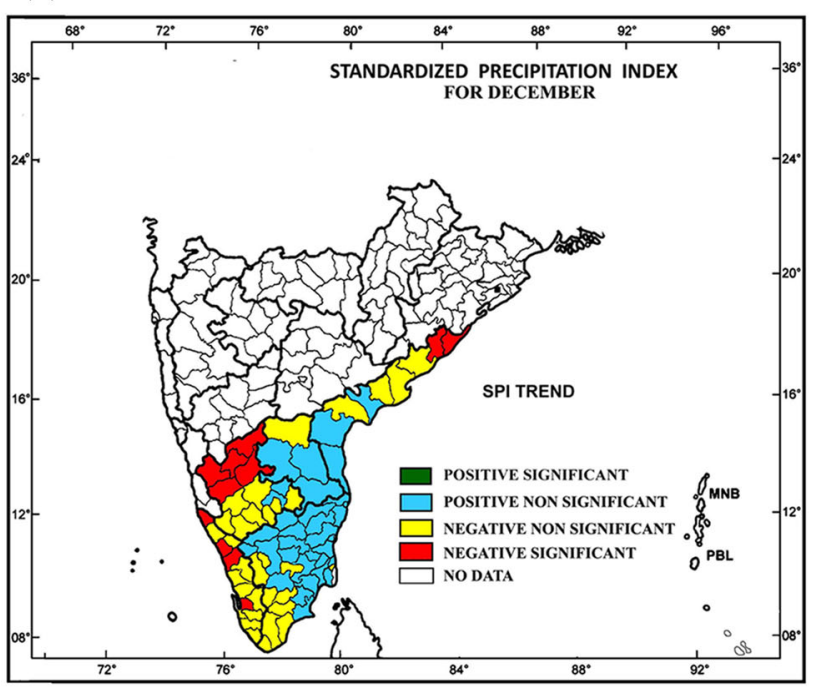

(b)

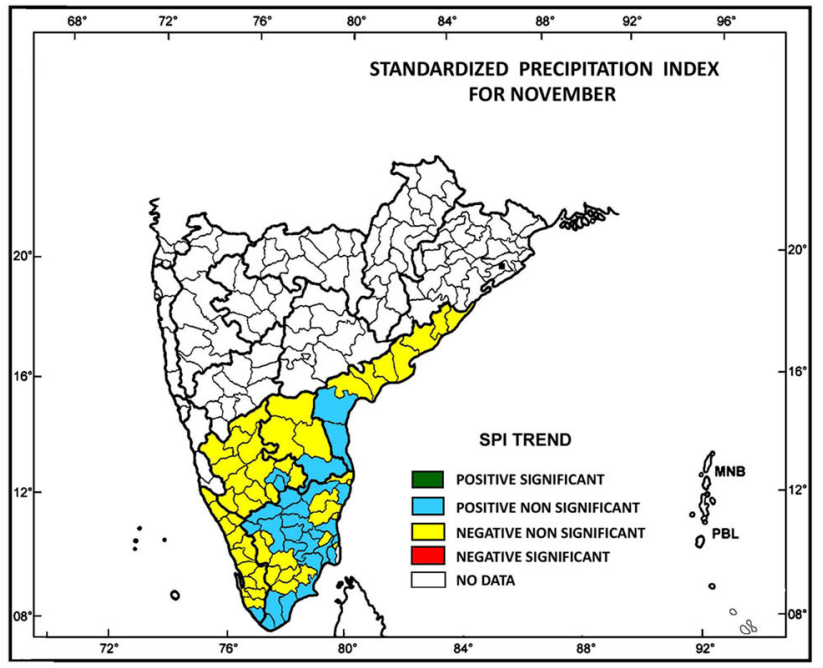

(d)

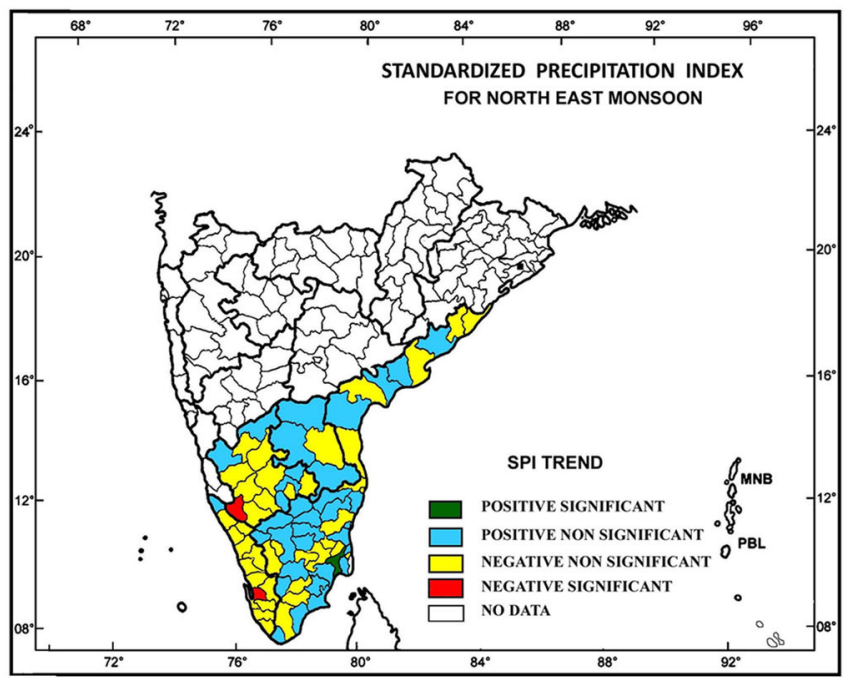

Figure 6. Trends in district SPI for the five meteorological subdivisions affected by northeast monsoon for (a) October, (b) November, (c) December and (d) three months October-December cumulative period.

10-20\% over the remaining districts of the five meteorological subdivisions during northeast monsoon. In most of the southern districts of Tamil Nadu probability of drought is high and is the range $15-20 \%$.

\section{Relationship of tropical Pacific SST with SPI}

The Indian monsoon rainfall has the strongest relationship with the equatorial eastern Pacific SSTs (Webster et al. 1998). Since drought is a slow moving process, association of drought occurrences with equatorial eastern Pacific SSTs can be better investigated. We have taken mean NINO 3.4 SST anomaly for the four-month period (JuneSeptember) for identifying the relationship of it with the four months (June-September) district SPI and also mean NINO 3.4 SST anomaly for the three-month period (October-December) for identifying the relationship of it with the three months (October-December) district SPI of the five meteorological subdivisions of India affected by northeast monsoon. It has been seen that standardized precipitation index has significant negative correlation for most of the districts of the country except for the districts of eastern and northeastern states during southwest monsoon (figure 8a). SPI for the few districts of northeastern India has 
(a)

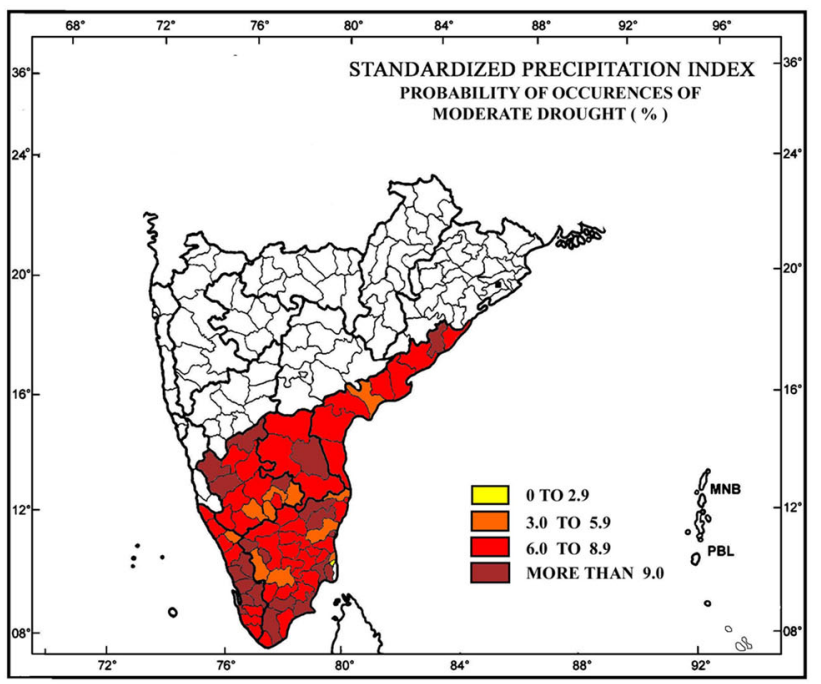

(c)

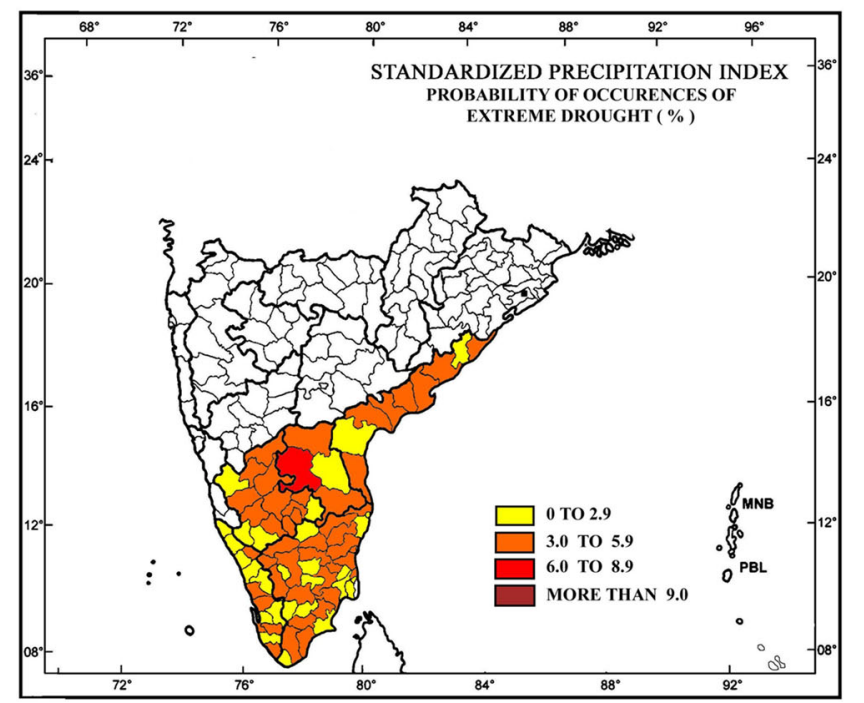

MINISTRY OF EARTH SCIENCES
INDIA METEOROLOGICAL DEPARTMENT

(b)

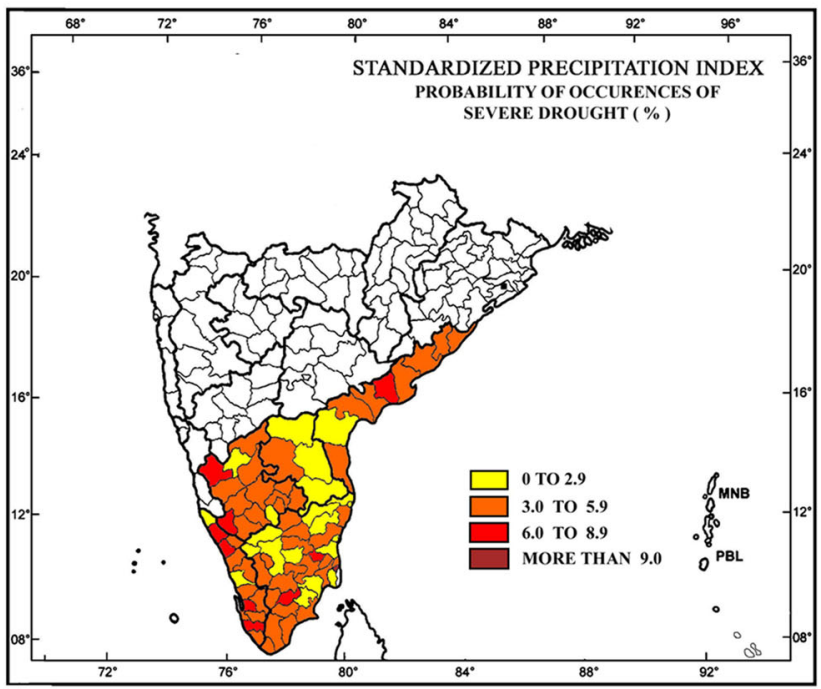

(d)

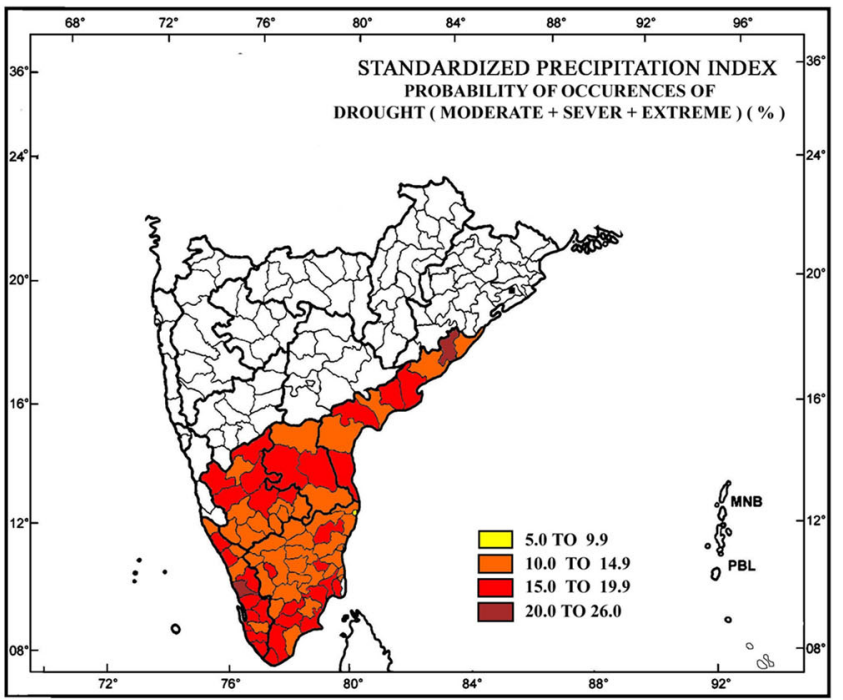

Figure 7. Probability of occurrences of drought in different categories during northeast monsoon (October-December) over five meteorological subdivisions of India.

significant positive correlation. However, mostly positive correlation present between district SPI and NINO 3.4 SST anomaly is for the three-month period (October-December) (figure 8b). Temporal correlation of four months (June-September) average SST with all India four months (JuneSeptember) SPI is shown in figure 9(a) to know spatial pattern of the relation of all India SPI with global SST. High negative and significant correlation is present with SST over NINO regions with maximum negative over NINO 3.4 region. Weak negative correlation exists with the SST over western Indian Ocean indicating minimum influence of IOD (Indian Ocean Dipole) on drought occurrences over India. Significant positive correlation (more than 0.3 ) of SPI with north pacific SST over $40^{\circ} \mathrm{N}$ along the date line can be identified indicating negative influence on drought over India during southwest monsoon. Figure 9(b) gives the global SST correlation with standardized precipitation index of southern peninsular India region affected by northeast monsoon during October-December (OND). Positive correlation of SPI with SST over NINO regions can be seen. But the significant positive correlation (between 0.25 and 0.3 ) only exists in eastern part of NINO 4 region between $150^{\circ}$ and $160^{\circ} \mathrm{W}$, but not over NINO 3 region. Maximum positive correlation (more than 0.3 ) can 
(a)

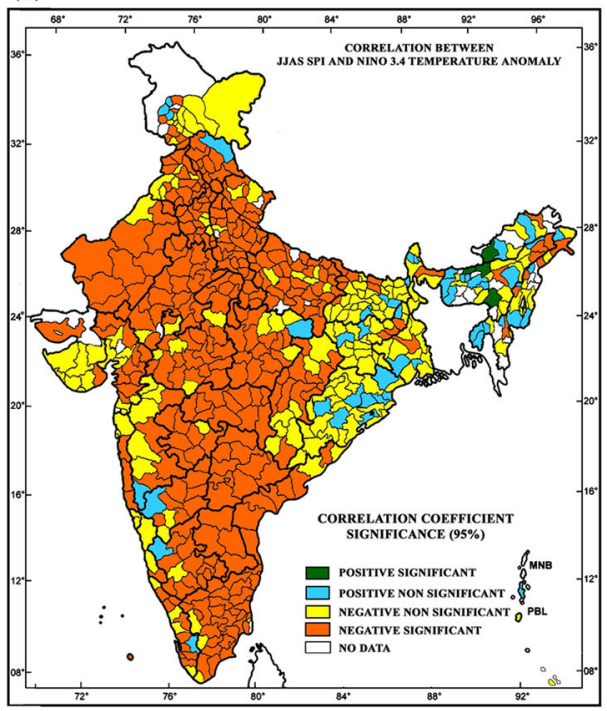

(b)

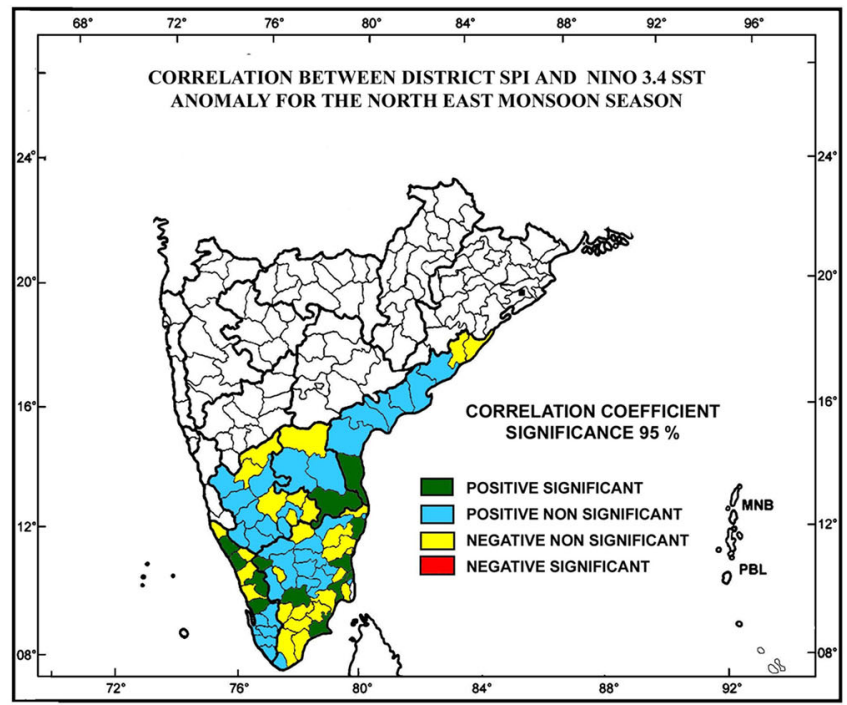

Figure 8. Correlation Coefficient (CC) of NINO3.4 SST index with district SPI over (a) India during southwest monsoon and (b) five meteorological subdivisions of south peninsular India during north east monsoon.

(a)

Global SST Correlation with All India SPI for JJAS

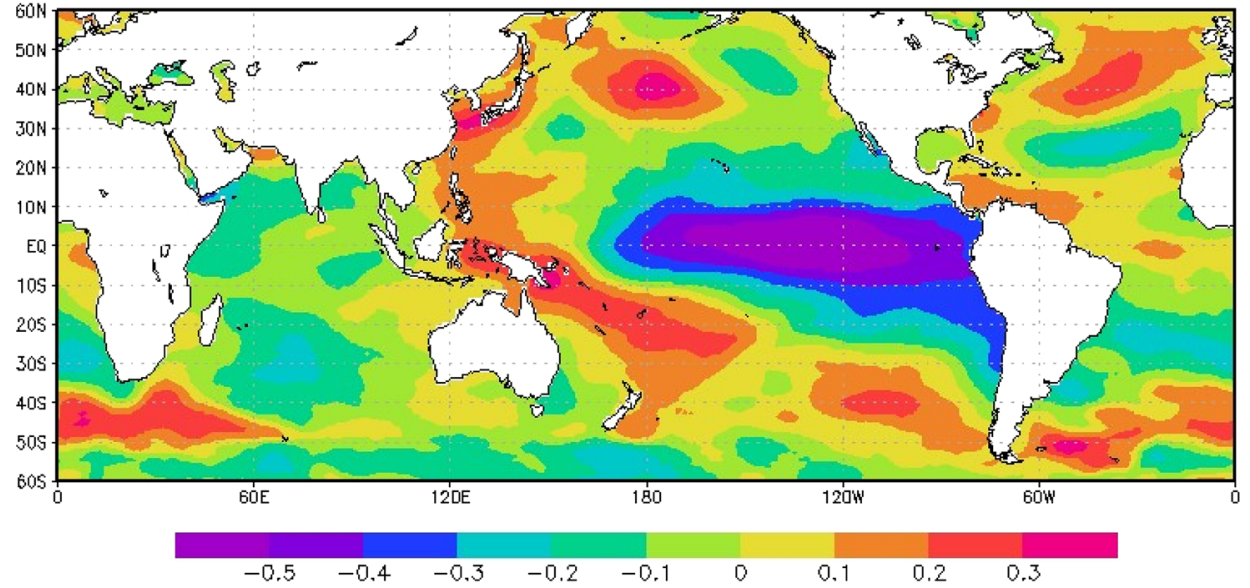

(b)

Global SST Correlation with SPI of South Peninsular INDIA for OND

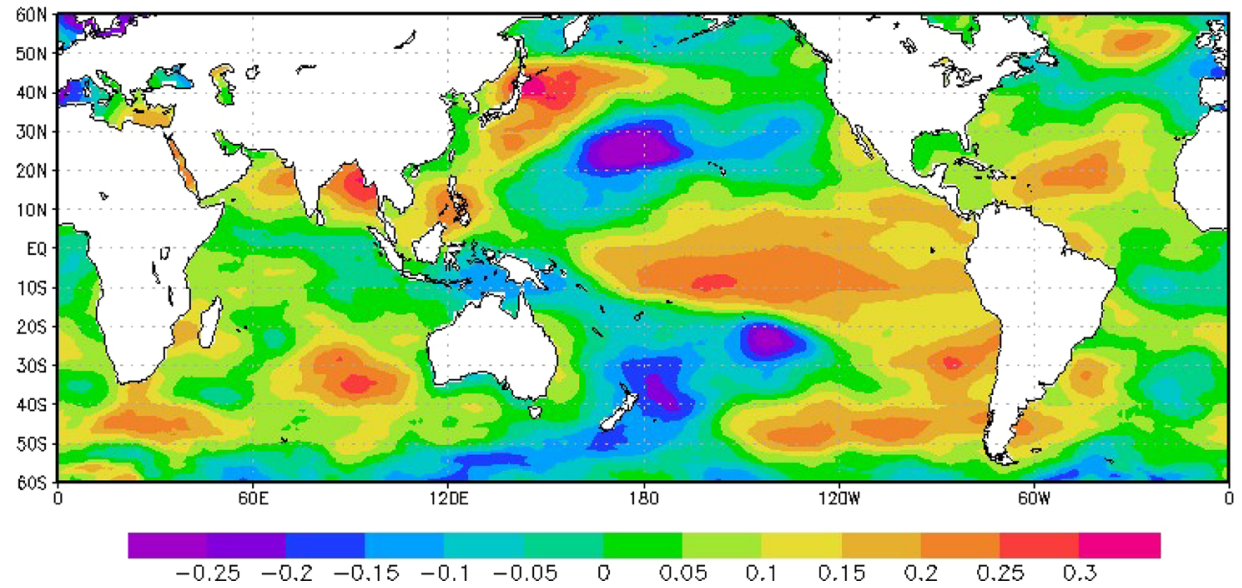

Figure 9. Global SST correlation with standardized precipitation index of (a) all India during June-September (JJAS) and (b) southern peninsular India affected by northeast monsoon during October-December (OND). 
be seen with SST over North Pacific Ocean near Japan.

\section{Conclusions}

Trends and variability of meteorological drought based on 115 years (1901-2015) of data over the districts of India are analysed based on standardized precipitation index. It has been found that in all the years when southwest monsoon rainfall was below normal, SPI values were -1 or less and thus in moderate, severe or extremely severe drought categories. During the period 1901-2015, there were 4 years, viz., 1965, 1972, 2002 and 2009 when SPI was in the extremely dry category and out of that 1972 was the most extremely dry. SPI values for the composite years when all India rainfall was less than $-10 \%$ shows that only $7.5 \%$ of the area of the country was under moderate drought category, while $88 \%$ was under mildly dry category. However, more than $30 \%$ of the area of the country was under moderate/severe/extreme drought conditions in the case of composite years when all India rainfall was less than or equal to $-15 \%$ or $-20 \%$ of normal. This suggests that the monsoon year can be considered as all India drought year if the rainfall is less than or equal to $-15 \%$ of its normal.

Trend analysis of district SPI indicates that the drought occurrences in subdivisions, viz., east Uttar Pradesh, Bihar and Assam \& Meghalaya are most alarming, while the subdivisions like Kerala, Tamil Nadu, Chhattisgarh, Jharkhand, Odisha, east Madhya Pradesh, Uttaranchal, west Uttar Pradesh, Punjab, Himachal Pradesh are also in alarming stage as many districts in these meteorological subdivisions reported increasing trends in drought occurrences.

Probability of drought occurrences over the districts based on 115 years of data varies between 10 and $26 \%$, with central and peninsular India having the higher probabilities. Trend analysis on the time series of percentage of area under drought condition shows seven subdivisions, viz., Uttarakhand, east Uttar Pradesh, Jharkhand, Chhattisgarh, Assam \& Meghalaya, Nagaland-Manipur-Mizoram \& Tripura and Kerala having the significant increasing trend in the area under drought condition. Most of the parts of eastern and northeast India show increasing trend in percentage of area under drought condition (SPI in the moderately dry, severely dry or extremely severe dry conditions). However, no subdivision shows significant decrease in area under drought condition.
Since the northeast monsoon plays significant role in the economy and on the society of south peninsular India, we have investigated meteorological drought over this region also. For the northeast monsoon season October-December, one district of south interior Karnataka and one district of Kerala show significant decreasing trend, while one district of Tamil Nadu shows significant increasing trend in SPI. Probability of moderate drought is around 6 $10 \%$, while extreme drought is around $3-6 \%$ over most of the districts. Probability of drought of all types is maximum (20-26\%) in one district of coastal Andhra Pradesh and one district of Kerala while it is varying from 10-20\% over the remaining districts of five meteorological subdivisions during northeast monsoon. Probability of drought is high and in the range $15-20 \%$ over most of the southern districts of Tamil Nadu.

ENSO has a significant role in the meteorological drought occurrences over Indian region. During southwest monsoon season, NINO 3.4 SST has significant negative correlation with SPI over almost all the districts of the country except for eastern and northeastern parts of India and some isolated over mostly western parts of the country. But during northeast monsoon NINO 3.4 has significant positive impact on SPI as it has positive correlation over most of the districts of the five meteorological subdivisions of south peninsular India affected by northeast monsoon. For seven districts of Tamil Nadu, one district of coastal Andhra Pradesh, one district of Rayalseema and four districts of Kerala, the positive correlation is significant at 95\% level. All India drought has strong positive correlation (negative correlation with SPI) with SST over NINO regions with maximum correlation over NINO 3.4 region. Indian Ocean Dipole has minimum (no significance correlation) influence on the meteorological drought over India. Alternately, a strong and significant positive correlation of all India SPI with SST over north Pacific is centred on $40^{\circ} \mathrm{N}$. For the northeast monsoon over south peninsular India, influence of SST over NINO regions on drought is much less than during southwest monsoon period.

\section{Acknowledgements}

Authors are thankful to DGM and Head, Climate Research and Services of India Meteorological Department for guidance and encouragement for this work. The authors also express their gratitude 
to the referees whose critical comments helped to improve the paper to a great extent.

\section{References}

Bordi I, Fraedrich K, Jiang J M and Sutera A 2004 Spatiotemporal variability of dry and wet periods in eastern China; Theor. Appl. Climatol. 79 81-91.

Burn D H and Hag-Elnur MA 2002 Detection of hydrologic trend and variability; J. Hydrol. 255 107-122.

Chanda M and Maity R 2015 Meteorological drought quantification with standardized precipitation anomaly index for the regions with strongly seasonal and periodic precipitation; J. Hydrol. Eng. ASCE 20(12) 06015007-106015007-8.

Dai A 2011 Drought under global warming: A review; Clim. Change 2 45-65.

Dai A, Trenberth K E and Qian T 2004 A global dataset of Palmer Drought Severity Index for 1870-2002: Relationship with soil moisture and effects of surface warming; $J$. Hydrometeorol. 5 1117-1130.

Edwards D C, McKee T B 1997 Characteristics of 20th century drought in the United States at multiple time scales; Climatology Rep. 97-2, Colorado State University, Dept. of Atmospheric Science, Fort Collins, Colorado, $155 \mathrm{p}$.

Guhathakurta P 2003 Drought in districts of India during the recent all India normal monsoon years and its probability of occurrence; Mausam 54 542-545.

Guhathakurta P, Koppar A L, Krishan U and Menon P 2011 New rainfall series for the districts, meteorological subdivisions and country as whole of India; National Climate Centre Research Report No: 2/2011, India Meteorological Department, Pune, India.

Guhathakurta P, Rajeevan M, Sikka D R and Tyagi A 2015 Observed changes in southwest monsoon rainfall over India during 1901-2011; Int. J. Climatol. 35 1881-1898.

Hayes M J, Svoboda M D, Wilhite D A and Vanyarkho O V 1999 Monitoring the 1996 drought using the standardized precipitation index; Bull. Am. Meteorol. Soc. 80 429-438.

Heim R R 2002 A review of twentieth century drought indices used in the United States; Bull. Am. Meteorol. Soc. 83 1149-1165.

Hirsch R M, Slack J R and Smith R A 1982 Techniques of trend analysis for monthly water quality data; Water Resour. Res. 18 107-121.

Hughes B L and Saunders M A 2002 A drought climatology for Europe; Int. J. Climatol. 22 1571-1592.

Kendall M G 1975 Rank Correlation Measures; Charles Griffin, London.

Kim D W, Byun H R and Choi K S 2009 Evaluation, modification, and application of the effective drought index to 200-year drought climatology of Seoul, Korea; J. Hydrol. 378 1-12.

Kucharski F, Molteni F and Yoo J H 2006 SST forcing of decadal Indian Monsoon rainfall variability; Geophys. Res. Lett. 33 L03709, https://doi.org/10.1029/2005GL025371.

Lettenmaier D P, Wood E F and Wallis J R 1994 Hydroclimatological trends in the continental United States, 1948-88; J. Climate 7 586-607.
Mallya G, Mishra V, Niyogi D, Tripathi S and Govindaraju R 2016 Trends and variability of droughts over the Indian monsoon region; Wea. Clim. Extremes, pp. 1243-1268.

Mann H B 1945 Nonparametric Tests against Trend; Econometrica 13 245-259.

Moradi H R, Rajabi M and Faragzadeh M 2011 Investigation of meteorological drought characteristics in Fars Province, Iran; Catena 84 35-46.

McKee T B, Doesken N J and Kliest J 1993 The relationship of drought frequency and duration to timescales; In: Proc. 8th Conf. on Applied Climatology, Anaheim, CA, American Meteorological Society, Boston, MA, 17-22 January, pp. 179-184.

Min S K, Kwon W T, Park E H and Choi Y 2003 Spatial and temporal comparisons of droughts over Korea with East Asia; Int. J. Climatol. 23 223-233.

Mishra A K and Singh V P 2010 A review of drought concepts; J. Hydrol. 391 202-216.

Nafarzadegana A R, Zadeha M R, Kherada M, Ahania H, Gharehkhania A, Karampoora M A and Kousari M R 2012 Drought area monitoring during the past three decades in Fars Province, Iran; Quat. Int. 250 $27-36$.

Niranjan Kumar, Rajeevan M, Pai D S, Srivastava A K and Preethi B 2013 On the observed variability of monsoon droughts over India; Wea. Clim. Extremes 1 $42-50$.

Pai D S, Latha Sridhar, Guhathakurta P and Hatwar H R 2011 District-wide drought climatology of the southwest monsoon season over India based on standardized precipitation index (SPI); Nat. Hazards 59 1797-1813. https:// doi.org/10.1007/s11069-011-9867-8.

Palmer W C 1965 Meteorological Drought; US Department of Commerce, Weather Bureau: Washington, DC.

Patel N R, Chopra P and Dadhwal V K 2007 Analyzing spatial patterns of meteorological drought using standardized precipitation index; Meteorol. Appl. 14 329-336.

Piccarreta M, Capolongo D and Boenzi F 2004 Trend analysis of precipitation and drought in Basilicata from 1923 to 2000 within a southern Italy context; Int. J. Climatol. 24 907-922.

Quiring S M and Papakryiakou T N 2003 An evaluation of agricultural drought indices for the Canadian prairies; Agric. For. Meteor. 18 49-62.

Seiler R A, Hayes M J and Bressan L 2002 Using the standardized precipitation index for flood risk monitoring; Int. J. Climatol. 22(11) 1365-1376.

Vergni L and Todisco F 2011 Spatio-temporal variability of precipitation, temperature and agricultural drought indices in central Italy; Agric. For. Meteor. 151 301-313.

Webster P J, Magana V O, Palmer T N, Shukla J, Tomas R A, Yanai M and Yasunari T 1998 Monsoons: Processes, predictability, and the prospects for prediction; J. Geophys. Res. 103 14,451-14,510.

World Meteorological Organization 2012 Standardized Precipitation Index User Guide, WMO-No. 1090.

Wu H, Svoboda M D, Hayes M J, Wilhite D A and Wen F 2007 Appropriate application of the standardized precipitation index in arid locations and dry seasons; Int. J. Climatol. 27 65-79. 
Zhai J, Su B, Gao C and Jiang T 2010 Spatial variation and trends in PDSI and SPI indices and their relation to streamflow in 10 large regions of China; J. Climate 23 649-663.

Corresponding editor: RAJIB MAITY
Zhang Q, Xu C-Y and Zhang Z 2008 Observed changes of drought/wetness episodes in the Pearl River basin, China, using the standardized precipitation index and aridity index; Theor. Appl. Climatol. 98 89-99. 